\title{
The action of the $\beta$-agonist clenbuterol on protein and energy metabolism in fattening wether lambs
}

\author{
By J. C. MACRAE, PAT A. SKENE, ALEXMARY CONNELL, \\ VIVIEN BUCHAN AND G. E. LOBLEY
}

Rowett Research Institute, Bucksburn, Aberdeen AB2 $9 S B$

(Received 9 November 1987 - Accepted 23 December 1987)

1. Five Greyface wethers $(42-45 \mathrm{~kg})$ fed on various fixed amounts of dried grass pellets (either approximately $1 \cdot 3$ times maintenance or 2 times maintenance) by means of belt-type continuous feeders were housed in opencircuit respiration chambers for periods of $45 \mathrm{~d}$. Between days 15 and 35 they received daily oral doses of $1.5 \mathrm{mg}$ of the $\beta$-adrenergic agonist clenbuterol (adsorbed on to the feed). Continuous energy and nitrogen balance measurements each of $5 \mathrm{~d}$ duration were conducted throughout the chamber confinement.

2. On six occasions (twice during the $15 \mathrm{~d}$ pre-clenbuterol period, on days $+4,+11$ and +18 of clenbuterol administration and once during the post-treatment period) animals were infused with $\left[1-{ }^{14} \mathrm{C}\right]$ leucine to determine the rates of leucine oxidation and the amounts of leucine available for protein synthesis.

3. Clenbuterol administration caused a marked increase in $\mathrm{N}$ retention $(2-3 \mathrm{~g} \mathrm{~N} / \mathrm{d} ; P<0.001)$ throughout the $20 \mathrm{~d}$ treatment period. It also increased $(P<0.00 \mathrm{l})$ the energy expenditure of the animals (on average by $1.1 \mathrm{MJ} /$ $\mathrm{d}$ over the first $5 \mathrm{~d}$, compared with immediate pretreatment values, and $0.6 \mathrm{MJ} / \mathrm{d}$ over the $20 \mathrm{~d}$ period, compared with the mean of pre- and post-treatment control values). The effect of treatment was calculated to result, on average, in the daily retention of 19 (SE 1.5) g more protein and 30 (SE 5.5) g less fat.

4. During clenbuterol treatment leucine oxidation was reduced $(P<0.01)$. However, values for the amounts of leucine available for protein synthesis were equivocal, with an increase $(P<0.001)$ on day 11 of treatment, but no change on days 4 and 18 .

5. Withdrawal of the clenbuterol resulted in rapid alterations of $\mathrm{N}$ and energy metabolism towards those expected of control animals of that weight.

The assertion that over-consumption of animal fat is detrimental to human health (National Advisory Committee on Nutrition Education, 1983; Department of Health and Social Security, 1984) has intensified the interest in methods which induce a leaner carcass conformation in growing animals. Some manipulation can be achieved by nutritional means (Turgeon et al. 1986) but economic considerations limit the extent of such applications. Within the genetic constraints of any particular breed, alternative ways of decreasing the ratio of fat gain:protein gain in growing and fattening animals usually involve the administration of exogenous compounds, e.g. ionophores, anabolic steroids, growth hormone, etc.

The phasing-out, within the European Economic Community at least, of the use of anabolic steroids has given added impetus to the search for alternative manipulators of the growth process. Recent interest has focussed on the range of $\beta$-adrenergic agonists, e.g. clenbuterol and cimaterol, which in growth trials involving poultry, pigs, sheep and cattle have been shown markedly to increase the areas of specific muscles, while concomitantly reducing body fat (Baker et al. 1984; Dalrymple et al. 1984a, b; Ricks et al. 1984; Beerman et al. 1986).

At present the majority of metabolic studies on the action of the $\beta$-agonists have been confined to rats where, for muscle protein metabolism at least, the evidence as to their mode of action is contradictory, with reports of both increases in protein synthesis (Emery et al. 1984) and decreases in protein degradation (Reeds et al. 1986). The present study represents the first stage in an examination of the action of clenbuterol on protein and energy metabolism in sheep. The protocol involved determination of the kinetics of energy 
expenditure and whole-body leucine metabolism. A preliminary report of these findings has appeared previously (MacRae et al. 1986).

\section{EXPERIMENTAL}

\section{Animals and diet}

Five Greyface wethers (initial weight $42-45 \mathrm{~kg}$ ) were accustomed to metabolism crates and to spending extended periods in an open-circuit respiration chamber. They were given rations of pelleted dried grass (23.5 g nitrogen/ $\mathrm{kg}$ dry matter (DM), $9.9 \mathrm{MJ}$ metabolizable energy (ME)/kg DM). Sheep nos. 92, 134 and 139 received a ration approximately equal to 2 times maintenance energy intake $(1600-1800 \mathrm{~g} / \mathrm{d}$ as fed (AF); maintenance assessed as $400 \mathrm{~kJ} / \mathrm{kg}$ live body-weight $(\mathrm{LBW})^{0.75}$ ) while sheep nos. 180 and 181 received 1100 and $1300 \mathrm{~g} / \mathrm{d}$ AF respectively. All rations were delivered by means of belt-type continuous feeders (Sutherland et al. 1964). The intake of each sheep was held constant for the duration of the experiment. Rations for individual sheep were prepared for the complete experimental period at a single weighing from a mixed batch of diet.

\section{Experimental design}

Each animal was prepared with two indwelling silastic catheters (Dow Corning, Health Care Group, Reading), one in each jugular vein. One catheter (1.02 $\mathrm{mm}$ i.d., $2 \cdot 16 \mathrm{~mm}$ o.d.) was inserted approximately $250 \mathrm{~mm}$ and used for sampling while the other $(0.76 \mathrm{~mm}$ i.d., $1.65 \mathrm{~mm} \mathrm{o.d}$.) was placed with its tip in the anterior vena cava (position identified with the aid of a blood pressure monitor; approximate distance $350 \mathrm{~mm}$ ) and used for infusion. Catheter patency was maintained for the total period of the experiment by continuous infusion of heparin solution ( $10 \mathrm{i} . \mathrm{u}$. heparin $/ \mathrm{ml}$ in $9 \mathrm{~g}$ sodium chloride $/ \mathrm{l} ; 6 \mathrm{ml} / \mathrm{h}$ ).

Each animal was confined to an open-circuit respiration chamber for a total period of $45 \mathrm{~d}$. Throughout that period they were harnessed to allow daily collection of faeces by chute (after Brockway, 1979) and urine by aspiration into $4 \mathrm{M}$-sulphuric acid. Excreta were pooled for analysis as $5 \mathrm{~d}$ batches. Heat production was estimated daily from gaseous exchange (Brouwer, 1965).

Measurements were made over three periods. The first was $15 \mathrm{~d}$ pretreatment. Next was a $20 \mathrm{~d}$ treatment period during which the sheep received daily $1.5 \mathrm{mg}$ clenbuterol, administered by adsorbing a solution of clenbuterol dissolved in $0.1 \mathrm{M}$-hydrochloric acid $(0.4 \mathrm{~g} / \mathrm{l})$ on to the grass pellets. Thereafter treatment with clenbuterol was discontinued and immediately a $10 \mathrm{~d}$ post-treatment period started.

\section{Leucine kinetics}

Leucine metabolism was measured on six separate occasions: twice in the pretreatment period, at days $+4,+11$ and +18 of clenbuterol administration, and finally once during the post-treatment period ( $7 \mathrm{~d}$ after drug withdrawal). The procedure was similar to that described previously (Lobley et al. 1985). Briefly, $\left[1-{ }^{14} \mathrm{C}\right]$ leucine in sterile saline $(9 \mathrm{~g}$ sodium chloride/l) was infused continuously $(25 \mathrm{~g} / \mathrm{h}, 0.2 \mu \mathrm{Ci} / \mathrm{g})$ for $8 \mathrm{~h}$. For the last $3 \mathrm{~h}$ of infusion blood samples $(20 \mathrm{ml})$ were withdrawn at $0.5 \mathrm{~h}$ intervals. The specific radioactivity and leucine concentration in blood were determined as described by Lobley et al. (1985). Expired ${ }^{14} \mathrm{CO}_{2}$ was determined directly by means of an on-line ionization chamber (volume 100 litres, constructed by J. Brockway, Rowett Research Institute) connected to the respiration chamber.

Calculation of leucine kinetics was as follows:

$$
\text { irreversible loss rate }(\mathrm{ILR} ; \mathrm{mmol} / \mathrm{h})=\frac{\text { infusion rate }(\mu \mathrm{Ci} / \mathrm{h})}{\text { SR blood free-leucine }(\mu \mathrm{Ci} / \mathrm{mmol})},
$$


where SR is specific radioactivity,

fractional oxidation rate $(\mathrm{FOR})=\frac{\mathrm{SR}^{14} \mathrm{CO}_{2}(\mu \mathrm{Ci} / \mathrm{mmol}) \times \mathrm{CO}_{2} \text { produced }(\mathrm{mmol} / \mathrm{h})}{\text { infusion rate }(\mu \mathrm{Ci} / \mathrm{h})}$,

$$
\text { leucine oxidized }(\mathrm{LO} ; \mathrm{mmol} / \mathrm{h})=\mathrm{FOR} \times \mathrm{ILR},
$$

leucine for protein synthesis $\left(\mathrm{ILR}_{\mathrm{syn}} ; \mathrm{mmol} / \mathrm{h}\right)=(1-\mathrm{FOR}) \times \mathrm{ILR}$.

Leucine oxidation and $\mathrm{ILR}_{\mathrm{syn}}$ can be converted from $\mathrm{mmol} / \mathrm{h}$ to approximate equivalents of protein $(\mathrm{g} / \mathrm{d})$ by the factor $\times 51.5$ (Lobley et al. 1980).

\section{Statistical procedures}

All values were analysed by two-way analysis of variance with orthogonal contrasts. The animal $\times$ day interaction cannot be used to provide an estimate of error as the animals will vary in the amount they change over the period. The interaction was therefore divided into three components: (1) (pretreatment control $v$. post-treatment control) $\times$ animal, (2) (treatment $v$. control) $\times$ animal, (3) other. Assuming natural changes to be largely linear the first component would be expected to be large. The second component, which provides a genuine estimate of error (but with only $4 \mathrm{df}$ ), was expected to be of the same order or slightly larger than the third. However, the analysis indicated that there was no difference between components (2) and (3), and the two components were combined to provide a measure of error. Unless otherwise stated all comparisons for treatment effects are against the combined values for pre- and post-treatment controls.

\section{RESULTS}

At the dosage of clenbuterol selected there were no feed refusals and no detectable change in the metabolizability of the ration.

\section{Effects on energy and $N$ retention}

A noticeable feature of the experiments was that the same level of clenbuterol administration evoked different responses in energy expenditure between the individual animals (see Table 1). Increases in energy expenditure over the first $5 \mathrm{~d}$ of treatment, which were greater than over the subsequent $15 \mathrm{~d}$ in all animals, varied from $0.55 \mathrm{MJ} / \mathrm{d}$ in sheep no. 134 to 1.65 and $1.91 \mathrm{MJ} / \mathrm{d}$ in sheep nos. 92 and 181 respectively. On average the energy expenditure during the first $5 \mathrm{~d}$ of treatment was elevated by $1.3 \mathrm{MJ} / \mathrm{d}$ compared with the immediate pretreatment value (Table 1). Despite a decline in energy expenditure thereafter the average energy expenditure over the 3 weeks was $0.9 \mathrm{MJ} / \mathrm{d}$ greater $(P<0.001$; Table 1$)$ than that during the mean of pre- and post-treatment control periods. Post-treatment heat productions were greater than the pretreatment values. This may represent a carryover effect of clenbuterol administration or, alternatively, may be a consequence of the increased weights of the animals at the latter part of the experiment (range of weight gain over the total period $3.0-11.5 \mathrm{~kg}$ ).

There was an immediate and sustained increase in $\mathrm{N}$ retention $(P<0.001$, Table 2$)$ as a result of clenbuterol administration. The magnitude of the increase $(2-3 \mathrm{~g} \mathrm{~N} / \mathrm{d})$ was similar for animals at low and high intakes. There were no apparent time-related changes in $\mathrm{N}$ retention during the $20 \mathrm{~d}$ treatment period. $\mathrm{N}$ retention declined when the drug was withdrawn.

\section{Changes in protein and fat retention}

From the combined $\mathrm{N}$ and energy balance values the retentions of protein and fat in individual animals can be calculated. Retained energy was assumed to be in the form of 
Table 1. Mean daily metabolizable energy $(M E)$ intakes and energy expenditures $(M J / d)$ of sheep given dried grass pellets before, during and after treatment with $1.5 \mathrm{mg}$ clenbuterol/d (Each value represents the mean of a $5 \mathrm{~d}$ measurement)

\begin{tabular}{|c|c|c|c|c|c|c|c|c|c|c|}
\hline \multirow{3}{*}{$\begin{array}{c}\text { Sheep } \\
\text { no. }\end{array}$} & \multirow{3}{*}{$\begin{array}{c}\mathrm{ME} \\
\text { intake } \\
(\mathrm{MJ} / \mathrm{d})\end{array}$} & \multicolumn{9}{|c|}{ Energy expenditure (MJ/d) } \\
\hline & & \multicolumn{3}{|c|}{ Pretreatment } & \multicolumn{4}{|c|}{ For treatment days: } & \multicolumn{2}{|c|}{ Post-treatment } \\
\hline & & $\mathrm{Cl}$ & $\mathrm{C} 2$ & C3 & $1-5$ & $6-10$ & $11-15$ & $16-20$ & $\mathrm{C} 4$ & $\mathrm{C5}$ \\
\hline 92 & $16 \cdot 37$ & ND & ND & $1 \mathrm{I} \cdot 03$ & $12 \cdot 62$ & $12 \cdot 77$ & ND & $11 \cdot 19$ & ND & $10 \cdot 47$ \\
\hline 134 & $14 \cdot 76$ & 9.04 & $9 \cdot 34$ & $9 \cdot 19$ & 9.74 & $9 \cdot 34$ & $9 \cdot 34$ & $9-49$ & $9 \cdot 01$ & 8.94 \\
\hline 139 & $14 \cdot 68$ & $8 \cdot 79$ & $9 \cdot 02$ & $9 \cdot 07$ & $9 \cdot 87$ & $9 \cdot 26$ & $9 \cdot 22$ & $9 \cdot 32$ & $9 \cdot 20$ & $9 \cdot 10$ \\
\hline 181 & $10 \cdot 00$ & ND & $9 \cdot 04$ & $9 \cdot 57$ & $11 \cdot 22$ & $10 \cdot 81$ & 10.92 & $10 \cdot 90$ & $10 \cdot 62$ & $10 \cdot 73$ \\
\hline 180 & $9 \cdot 20$ & $7 \cdot 33$ & $7 \cdot 41$ & 7.95 & 8.73 & $8 \cdot 80$ & $9 \cdot 05$ & $9 \cdot 19$ & 8.98 & $9 \cdot 12$ \\
\hline Mean* $\dagger$ & 13.00 & 8.96 & $9 \cdot 12$ & $9 \cdot 36$ & $10 \cdot 41$ & $10 \cdot 25$ & $10 \cdot 25$ & $10 \cdot 11$ & 9.65 & 9.67 \\
\hline
\end{tabular}

$\mathrm{C} 1, \mathrm{C} 2, \mathrm{C} 3, \mathrm{C} 4, \mathrm{C} 5$ are each $5 \mathrm{~d}$ control periods before $(\mathrm{Cl}-\mathrm{C} 3)$ and after $(\mathrm{C} 4-\mathrm{C} 5)$ treatment; ND, not determined.

* Mean values include estimates for missing values.

$\dagger$ Mean increase in energy expenditure over treatment period compared with pre- and post-treatment controls $0.9 \mathrm{MJ} / \mathrm{d}(P<0.001$; standard error of difference 0.27 , residual df 17$)$.

Table 2. Mean daily nitrogen intakes and $N$ retentions $(g N / d)$ of sheep given dried grass pellets before, during and after treatment with $1.5 \mathrm{mg}$ clenbuterol/d

(Each period represents mean of a $5 \mathrm{~d}$ measurement)

\begin{tabular}{|c|c|c|c|c|c|c|c|c|c|c|}
\hline \multirow{3}{*}{$\begin{array}{c}\text { Sheep } \\
\text { no. }\end{array}$} & \multirow{3}{*}{$\underset{\text { intake }}{\mathrm{N}}$} & \multicolumn{9}{|c|}{$\mathrm{N}$ retention $(\mathrm{g} \mathrm{N} / \mathrm{d})$} \\
\hline & & \multicolumn{3}{|c|}{ Pretreatment } & \multicolumn{4}{|c|}{ For treatment days: } & \multicolumn{2}{|c|}{ Post-treatment } \\
\hline & & $\mathrm{Cl}$ & $\mathrm{C} 2$ & C3 & $1-5$ & $6-10$ & $11-15$ & $16-20$ & $\mathrm{C} 4$ & C5 \\
\hline 92 & $39 \cdot 1$ & ND & ND & $11 \cdot 0$ & $11 \cdot 9$ & $11 \cdot 2$ & ND & $14 \cdot 8$ & ND & $7 \cdot 8$ \\
\hline 134 & 39.9 & $7 \cdot 2$ & 5.9 & $6 \cdot 1$ & ND & $13 \cdot 2$ & $10 \cdot 6$ & $10 \cdot 8$ & $9 \cdot 0$ & $9 \cdot 9$ \\
\hline 139 & 36.7 & 11.6 & 8.4 & $9 \cdot 3$ & $10 \cdot 8$ & ND & $11 \cdot 8$ & $10 \cdot 5$ & $7 \cdot 4$ & 4.7 \\
\hline 181 & $25 \cdot 5$ & ND & $6 \cdot 3$ & 3.9 & 8.7 & $6 \cdot 2$ & $6 \cdot 8$ & 7.8 & $4 \cdot 4$ & $4 \cdot 1$ \\
\hline 180 & $21 \cdot 6$ & $4 \cdot 5$ & $5 \cdot 5$ & $5 \cdot 3$ & $6 \cdot 1$ & $6 \cdot 5$ & $8 \cdot 5$ & $6 \cdot 4$ & $2 \cdot 8$ & $2 \cdot 3$ \\
\hline Mean*† & $32 \cdot 6$ & $8 \cdot 3$ & $7 \cdot 5$ & $7 \cdot 1$ & $9 \cdot 8$ & $9 \cdot 5$ & $10 \cdot 1$ & $10 \cdot 0$ & $6 \cdot 4$ & $5 \cdot 8$ \\
\hline
\end{tabular}

$\mathrm{Cl}, \mathrm{C} 2, \mathrm{C} 3, \mathrm{C} 4, \mathrm{C} 5$ are each $5 \mathrm{~d}$ control periods before $(\mathrm{Cl}-\mathrm{C} 3)$ and after $(\mathrm{C} 4-\mathrm{C} 5)$ treatment; ND, not determined.

* Mean values include estimates for missing values.

$\dagger$ Mean increase in $\mathrm{N}$ retention over treatment period compared with pre- and post-treatment controls $2.8 \mathrm{~g} \mathrm{~N} / \mathrm{d}$ $(P<0.001 ;$ standard error of difference 0.79 , residual df 17$)$.

either protein $(\mathrm{N} \times 6.25$; assumed energy value $23.6 \mathrm{MJ} / \mathrm{kg}$ ) or fat (assumed energy value $39.6 \mathrm{MJ} / \mathrm{kg}$ ). Before treatment the animals given the twice maintenance level of intake (sheep nos. 92, 134 and 139) were retaining approximately $5 \mathrm{MJ}$ energy/d in the proportions $60 \mathrm{~g}$ protein: $90 \mathrm{~g}$ fat; the other two animals fed on the lower intake were retaining 0.8 and $1.5 \mathrm{MJ} / \mathrm{d}$, mainly as protein $(35 \mathrm{~g} / \mathrm{d})$. Treatment with clenbuterol caused a marked alteration in the calculated ratio of protein:fat accreted. The calculated differences in individual sheep between pretreatment and treatment retention of protein 


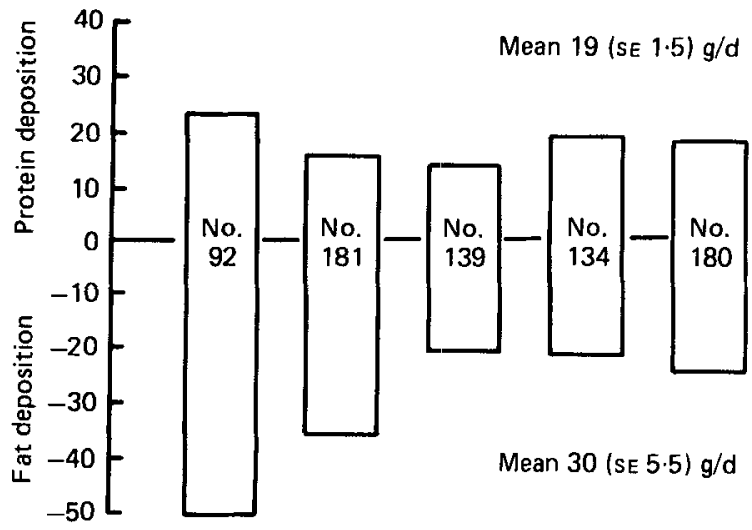

Fig. 1. Alterations in protein and fat deposition $(\mathrm{g} / \mathrm{d})$ for individual animals over the period during which they received $1.5 \mathrm{mg}$ clenbuterol/d. Results are expressed against the mean pre- and posttreatment values for energy and nitrogen deposition (from Tables 1 and 2). Numbers within the bars refer to individual sheep identification. All animals showed a gain in protein and a decrease in fat deposition during treatment.

Table 3. Rates of leucine oxidation $(\mathrm{mmol} / \mathrm{h})$ in sheep given dried grass pellets before, during and after treatment with $1.5 \mathrm{mg}$ clenbuterol/d

\begin{tabular}{|c|c|c|c|c|c|c|c|}
\hline \multirow{3}{*}{$\begin{array}{l}\text { Sheep } \\
\text { no. }\end{array}$} & \multirow{3}{*}{$\begin{array}{c}\text { Nitrogen } \\
\text { intake } \\
(\mathrm{g} \mathrm{N} / \mathrm{d})\end{array}$} & \multicolumn{6}{|c|}{ Leucine oxidation $(\mathrm{mmol} / \mathrm{h})$} \\
\hline & & \multicolumn{2}{|c|}{ Pretreatment } & \multicolumn{3}{|c|}{ For treatment days: } & \multirow{2}{*}{$\begin{array}{l}\text { Post-treatment } \\
\text { C3 }\end{array}$} \\
\hline & & $\mathrm{Cl}$ & $\mathrm{C} 2$ & 4 & 11 & 18 & \\
\hline 92 & $39 \cdot 1$ & ND & 3.94 & $2 \cdot 80$ & ND & 2.45 & 2.97 \\
\hline 134 & $39 \cdot 9$ & $3 \cdot 25$ & $3 \cdot 54$ & 3.89 & $2 \cdot 37$ & $2 \cdot 96$ & 2.67 \\
\hline 139 & $36 \cdot 7$ & $2 \cdot 55$ & $2 \cdot 70$ & $2 \cdot 51$ & $2 \cdot 65$ & $2 \cdot 17$ & $3 \cdot 49$ \\
\hline 181 & $25 \cdot 5$ & ND & $2 \cdot 54$ & 1.60 & 1.65 & $1 \cdot 37$ & $2 \cdot 21$ \\
\hline 180 & $21 \cdot 6$ & 1.78 & 1.64 & $1 \cdot 15$ & $1 \cdot 25$ & $1 \cdot 18$ & $1 \cdot 55$ \\
\hline Mean*† & $32 \cdot 6$ & $2 \cdot 77$ & $2 \cdot 87$ & $2 \cdot 39$ & $2 \cdot 09$ & 2.08 & $2 \cdot 58$ \\
\hline
\end{tabular}

$\mathrm{Cl}, \mathrm{C} 2, \mathrm{C} 3$ each represent control measurements made either before $(\mathrm{C} 1-\mathrm{C} 2)$ or after (C3) treatment ; ND, not determined.

* Mean values involve estimates for missing values.

$\dagger$ Mean decrease in leucine oxidation over treatment period compared with pre- and post-treatment controls $0.6 \mathrm{mmol} / \mathrm{h}(P<0.001$; standard error of difference 0.24 , residual $\mathrm{df} 13)$.

and fat, as a result of clenbuterol administration to individual animals, are shown in Fig. 1 . The $\beta$-agonist increased the rate of protein deposition and reduced the rate of fat deposition, with an overall decrease in total energy retention. There was considerable between-animal variability particularly in the effect of fat deposition. Rates of protein deposition were, on average, increased by 19 (SE 1.5) g/d (by approximately $40 \%$ of the rate of accretion in the control animals). Rates of fat deposition were reduced by 30 (SE $5 \cdot 5) \mathrm{g} / \mathrm{d}$; this represents a reduction of $30 \%$ on the rate of fat gain for the high-intake animals, and an actual promotion of fat mobilization in the animals on the lower intake.

\section{Protein turnover}

The rates of leucine oxidation and of leucine available for protein synthesis calculated from leucine ILR and FOR are given in Tables 3 and 4. Clenbuterol caused a significant 
Table 4. Amounts of leucine available for protein synthesis $\left(I L R_{s y n} ; m m o l / h\right)$ in sheep given dried grass pellets before, during and after treatment with $1.5 \mathrm{mg}$ clenbuterol/d

\begin{tabular}{|c|c|c|c|c|c|c|c|}
\hline \multirow{3}{*}{$\begin{array}{l}\text { Sheep } \\
\text { no. }\end{array}$} & \multirow{3}{*}{$\begin{array}{c}\text { Nitrogen } \\
\text { intake } \\
(\mathrm{g} \mathrm{N} / \mathrm{d})\end{array}$} & \multicolumn{6}{|c|}{$\mathrm{ILR}_{\mathrm{syn}}(\mathrm{mmol} / \mathrm{h})$} \\
\hline & & \multicolumn{2}{|c|}{ Pretreatment } & \multicolumn{3}{|c|}{ For treatment days: } & \multirow{2}{*}{$\begin{array}{l}\text { Post-treatment } \\
\text { C3 }\end{array}$} \\
\hline & & $\mathrm{Cl}$ & $\mathrm{C} 2$ & 4 & 11 & 18 & \\
\hline 92 & $39 \cdot 1$ & ND & $10 \cdot 2$ & $9 \cdot 9$ & ND & $9 \cdot 8$ & $8 \cdot 7$ \\
\hline 134 & $39 \cdot 9$ & $7 \cdot 8$ & $7 \cdot 4$ & $7 \cdot 8$ & $8 \cdot 0$ & $7 \cdot 7$ & $7 \cdot 2$ \\
\hline 139 & $36 \cdot 7$ & $8 \cdot 6$ & $8 \cdot 5$ & $8 \cdot 6$ & $10 \cdot 1$ & $8 \cdot 2$ & $9 \cdot 1$ \\
\hline 181 & $25 \cdot 5$ & ND & $8 \cdot 4$ & 8.5 & $10-1$ & $7 \cdot 4$ & $8 \cdot 4$ \\
\hline 180 & 21.5 & $6 \cdot 3$ & 6.5 & $7 \cdot 4$ & $8 \cdot 0$ & $7 \cdot 7$ & $7 \cdot 2$ \\
\hline Mean* + & 32.6 & $8 \cdot 3$ & 8.2 & $8 \cdot 4$ & $9 \cdot 4$ & $8 \cdot 1$ & $8 \cdot 1$ \\
\hline
\end{tabular}

$\mathrm{Cl}, \mathrm{C} 2, \mathrm{C} 3$ each represent control measurements made either before (C1-C2) or after (C3) treatment; ND, not determined.

* Mean values involve estimates for missing values.

† Mean increase in ILR $_{\text {syn }}$ over treatment period compared with pre- and post-treatment controls $0.4 \mathrm{mmol} /$ h $(P<0.05 ;$ standard error of difference $0 \cdot 30$, residual df 13$)$.

reduction $(P<0.001)$ in $\mathrm{LO}$ throughout the treatment period. There was no significant increase in the flux of leucine to protein synthesis on days +4 and +18 . At day +11 of treatment, however, this rate was elevated $(P<0.001)$.

\section{DISCUSSION}

The actions of clenbuterol and certain other $\beta$-adrenergic compounds can be conveniently divided into two parts: the effects on energy expenditure and on protein gain. In experiments where intake has been controlled, or the administration of the drug has not stimulated voluntary food intake, there has been a reduction in either total body fat (calves, Williams et al. 1987; rats, Reeds et al. 1988), carcass fat (sheep, cattle and pigs; Ricks et al. 1984) or the estimated rate of fat deposition (sheep, present study). The reduction in lipid retention in the present study resulted partly as a consequence of an increased proportion of retained energy being as protein and partly because the rates of energy expenditure were increased. From consideration of ME intake and total energy deposition Williams et al. (1987) estimated that mean energy expenditure was increased, compared with controls, by $0.12(2.8 \mathrm{MJ} / \mathrm{d})$ over a $100 \mathrm{~d}$ treatment period in calves. This value is somewhat greater than the increase in heat production measured directly for sheep in the present study (mean $+0.6 \mathrm{MJ} / \mathrm{d} ; 0.07$ increase). The calorimetric determinations also highlight the initial marked increase in energy expenditure during the first 24-96 h, which is probably associated with other $\beta_{2}$-adrenergic effects, such as tachycardia. After this period the elevation in heat production was less but energy expenditure was still greater $(P<0.001)$ than that in control periods. Increased energy expenditures were also reported for the rat (Rothwell et al. 1983; Emery et al. 1984) but since in those experiments the clenbuterol-treated animals ate more than controls $(+0.13$ and +0.22 respectively), at least a portion of the increased heat production could have been the result of the greater intake.

The increased $\mathrm{N}$ retention observed in the present study represented an average daily improvement of $3 \mathrm{~g}$, or a proportional increase of 0.46 . The absolute increase is similar to that calculated from slaughter values on clenbuterol-treated calves, in which the 
proportional increase in rate of gain was only 0.08 (Williams et al. 1987). In rats, Emery et al. (1984) observed improvements in body protein gain of +0.22 over a $16 \mathrm{~d}$ treatment period, while for specific muscles Reeds et al. (1986) noted a doubling in the rate of protein retention in the initial phase of the action of the drug. The proportional improvements are to some extent misleading, dependent as they are on the initial gain in the control animals; nonetheless the absolute improvements appear to represent a persistent protein anabolic response, which can be observed for entire males as well as for castrates and females.

The improvement in protein deposition appears to be confined to skeletal and cardiac muscle, for in both rats (Reeds et al. 1986) and calves (Williams et al. 1987) no extra $\mathbf{N}$ gain could be detected for the other tissues. Indeed, in both species, a part of the improved carcass (muscle) retention appeared to be accomplished at the expense of the other tissues. Thus in the calf study carcass $\mathrm{N}$ gain was $0.45 \mathrm{~kg}$, whereas total $\mathrm{N}$ retention was only enhanced by $0.31 \mathrm{~kg}$. Similarly, in the rat study, by $21 \mathrm{~d}$ of clenbuterol treatment, the weights of liver and kidney in treated animals were lower $(P<0.05)$ than in untreated animals.

Based on intermediate $\mathrm{N}$ balance studies the rate of protein deposition in clenbuteroltreated calves was similar throughout the $100 \mathrm{~d}$ of treatment (Williams et al. 1987) and, in the present study, there were no obvious signs of the protein anabolic effect showing temporal changes. In young rats, however, the action of the drug is fairly short-lived, probably no longer than $14 \mathrm{~d}$ (Reeds et al. 1986). The reasons for this are not clear, although some restriction may be imposed by the ability of the skeleton to support the extra muscle mass. Increased weight, and protein content, for the muscles from the lower leg of the rat were enhanced by $0.23-0.33$ above the approximate tripling already achieved by normal growth for the controls. Clearly, in the larger and more slowly growing commercial species, such rapid fractional increases in growth do not occur, but if all the extra $\mathrm{N}$ retention observed in the present study were as muscle protein, this would also represent an increase in muscle: bone value of approximately $0 \cdot 2$.

The mechanism(s) by which the increased protein retention is achieved is controversial. In rats Emery et al. (1984) reported a stimulation of muscle protein synthesis at high daily doses of clenbuterol $\left(2 \times 1 \mathrm{mg} / \mathrm{kg}\right.$ body-weight; $\left.1200-1400 \mu \mathrm{g} / \mathrm{kg} \mathrm{LBW}{ }^{0.75}\right)$ but under these conditions food intake was also increased, a situation well-known to elevate protein synthesis (Reeds et al. 1980). In contrast Reeds et al. (1986), using daily dosages of clenbuterol more comparable $\left(200 \mu \mathrm{g} / \mathrm{kg}\right.$ body-weight; $\left.110 \mu \mathrm{g} / \mathrm{kg} \mathrm{LBW}^{0.75}\right)$ with those used both in the present study (28-35 $\mu \mathrm{g} / \mathrm{kg}$ body-weight; 75-90 $\left.\mu \mathrm{g} / \mathrm{kg} \mathrm{LBW}^{0.75}\right)$ and other growth trials with farm species (e.g. calves $20 \mu \mathrm{g} / \mathrm{kg}$ body-weight; $70 \mu \mathrm{g} / \mathrm{kg}$ $\mathrm{LBW}^{0.75}$; Williams et al. 1987), found no stimulation of fractional synthesis rate in either $\mathrm{m}$. gastrocnemius or $\mathrm{m}$. soleus. Indeed, they reported a significant decline in protein synthesis after the protein anabolic action of the drug had apparently ceased, and concluded that the primary increase in muscle protein content was due to a decrease in fractional breakdown rate. The situation may be more complex, however, since at days +4 and +11 of treatment, i.e. while anabolism was still actively proceeding, absolute synthesis (the product of fractional synthesis rate $\times$ protein mass) in the rat muscles did increase, despite no increase in food intake. Thus, while the initial action of the drug does appear to involve a decrease in protein degradation, later maintenance of the anabolism may require elevation of muscle total protein synthesis. Similar observations with sheep were reported by Bohorov et al. (1987), where improvements in the rate of protein gain in both $\mathrm{m}$. longissimus dorsi and $\mathrm{m}$. vastus lateralis were 0.33 greater in animals which received clenbuterol (approximately $400 \mu \mathrm{g} / \mathrm{kg}$ body-weight $/ \mathrm{d} ; 1060 \mu \mathrm{g} / \mathrm{kg} \mathrm{LBW}^{0.75}$ ). After $37 \mathrm{~d}$ of treatment muscle fractional protein synthesis rates were indistinguishable between control and treated lambs but total synthesis was elevated by $0.33-0.66$. The authors were also in 
general agreement with the conclusion that a decrease in muscle protein degradation was involved in the primary action of clenbuterol. Additional evidence which supports a partial role, at least, for a decline in muscle protein degradation comes from the reduced $N^{\top}$ methylhistidine elimination observed for treated as compared with control calves (Williams et al. 1987).

The measurement of leucine ILR through the blood pool allows a comparative estimate of whole-body kinetics, provided the drug treatment does not alter the relation between the SR of the leucyl-tRNAs and blood free leucine. In whole-animal terms, leucine oxidation (which can be equated to overall amino acid catabolism) declined as urinary $\mathrm{N}$ elimination decreased and $\mathrm{N}$ retention increased. The flux of leucine for protein synthesis was unaltered from control values at day +4 , was elevated at day +11 and declined again at day +18 . Only at day +11 were these changes significant $(P<0.001)$. The reasons for these trends are unclear, although the values at day +18 are similar to those reported by Bohorov et al. (1987) for plasma tyrosine flux in lambs compared, after $37 \mathrm{~d}$ of treatment with clenbuterol, with controls. In that report (Bohorov et al. 1987), tyrosine flux (uncorrected for oxidation) was slightly lower, but not significantly so, in the treated animals; this was despite an increase in absolute protein synthesis for certain muscles (see p. 463). The pattern in whole-body protein synthesis observed in the current study $\left(\operatorname{ILR}_{\mathrm{syn}} \times 51.5\right.$; from Table 4) is, however, similar to that observed for muscle total protein synthesis in rats treated with clenbuterol, i.e. no increase, increase and then decline (from Reeds et al. 1986). Muscle protein synthesis, however, makes a minor contribution to whole-body protein synthesis $(0.15-0.25$; Lobley et al. 1980) and, at day $+18, \mathrm{~N}$ retention is still augmented in sheep, whereas in rats the decline in absolute muscle synthesis appears to accompany the loss of the protein anabolic effect: thus such comparisons must be considered with caution. An additional complication involves the changes in carcass composition, as observed for example in calves (Williams et al. 1987), where there is actually a reduction in protein mass of the viscera compared with control animals. Tissues such as the gastrointestinal tract, liver, skin, etc. make important contributions to body protein turnover and changes in the metabolic activity of these tissues may produce profound effects on the kinetics of amino acid metabolism disproportionate to net changes in protein gain. The importance of these non-muscle tissues to the viability of the animal may require that 'resistance' to extended depletion through the action of an exogenous agent, be induced. Therefore, to compensate, the rates of synthesis in these tissues may be elevated until a new balance between the action of the drug and normal endogenous mechanisms is established. This may account for the increased rate of synthesis observed at day +11 , but obviously such speculations need to be tested by experiment.

Clearly, the $\beta$-agonist clenbuterol is a highly effective means of altering the relative rates of protein and fat deposition and, therefore, of changing the carcass conformation of the animal. Unfortunately, some problems are encountered with the use of clenbuterol, e.g. tachycardia, reduced blood pressure and, at dose rates above $1.5 \mathrm{mg} / \mathrm{d}$, inappetence in sheep (Brockway et al. 1987). Reeds et al. (1988) have shown that the effects of clenbuterol on energy expenditure and protein anabolism can be dissociated, at least in the rat: the use of selective $\beta$-antagonists prevented the elevated energy expenditure but maintained the protein anabolic response. This raises the possibility that suitable compounds could be synthesized which would retain the potential to improve protein gain without associated deleterious actions, making them more suitable for commercial application.

The authors wish to acknowledge the generous gift of the clenbuterol used in this experiment from Mr S. James, Coopers Animal Health, Berkhampstead, UK. They are also grateful for the statistical analysis carried out by Mrs Hazel Vint and the routine analysis of feed and excreta performed by members of the Institute Services Division. 


\section{REFERENCES}

Baker, P. K., Dalrymple, R. H., Ingle, D. L. \& Ricks, C. A. (1984). Journal of Animal Science 59, 1256-1261.

Beerman, D. H., Hogue, D. E., Fishell, V. K., Dalrymple, R. H. \& Ricks, C. A. (1986). Journal of Animal Science 62, $370-380$.

Bohorov, O., Buttery, P. J., Correia, J. H. R. D. \& Soar, J. B. (1987). British Journal of Nutrition 57, 99-107.

Brockway, J. M. (1979). Laboratory Practice 28, 139.

Brockway, J. M., MacRae, J. C. \& Williams, P. E. V. (1987). Veterinary Record 120, 381-383.

Brouwer, E. (1965). In Energy Metabolism, pp. 441-443 [K. L. Blaxter, editor]. New York and London: Academic Press.

Dalrymple, R. H., Baker, P. K., Doscher, M. E., Ingle, D. L., Paskavich, J. A. \& Ricks, C. A. (1984a). Journal of Animal Science 59, Suppl. 1, 212.

Dalrymple, R. H., Ricks, C. A., Baker P. K., Pensack, J. M., Gingher, P. E. \& Ingle, D. L. (1984 b). Poultry Science 63, 2376.

Department of Health and Social Security (1984). Diet and Cardiovascular Disease. Committee on Medical Aspects of Food Policy. Report on Health and Social Subjects no. 28. London: H. M. Stationery Office.

Emery, P. W., Rothwell, N. J., Stock, M. J. \& Winter, P. D. (1984). Bioscience Reports 4, 83-91.

Lobley, G. E., Connell, A., Mollison, G. S., Brewer, A. C., Harris, C. I. \& Buchan, V. (1985). British Journal of Nutrition 54, 681-694.

Lobley, G. E., Milne, V., Lovie, J. M., Reeds, P. J. \& Pennie, K. (1980). British Journal of Nutrition 43, 491-502.

MacRae, J. C., Lobley, G. E., Skene, P. A. \& James, S. (1986). Journal of Animal Science 63, Suppl. 1, 453.

National Advisory Committee on Nutrition Education (1983). A Discussion Paper on Proposals for Nutritional Guidelines for Health Education in Britain. London: Health Education Council.

Reeds, P. J., Cadenhead, A., Fuller, M. F., Lobley, G. E. \& McDonald, J. D. (1980). British Journal of Nutrition 43, 445-455.

Reeds, P. J., Hay, S. M., Dorwood, P. M. \& Palmer, R. M. (1986). British Journal of Nutrition 56, $249-258$.

Reeds, P. J., Hay, S. M., Dorwood, P. M. \& Palmer, R. M. (1988). Comparative Biochemistry and Physiology. (In the Press.)

Ricks, C. A., Dalrymple, R. H., Baker, P. K. \& Ingle, D. L. (1984). Journal of Animal Science 59, $1247-1255$.

Rothwell, N. J., Stock, M. J. \& Winter, P. D. O'B. (1983). Proceedings of the Nutrition Society 43, 71A.

Sutherland, T. M., Gupta, G. N., Reid, R. S. \& Murray, M. G. (1964). Proceedings of International Congress of Nutrition VI, Edinburgh 1964, p. 579. Edinburgh: Livingstone.

Turgeon, O. A., Brink, D. R., Bartle, S. J., Klopfenstein, T. J. \& Ferrell, C. L. (1986). Journal of Animal Science 63, 770-780.

Williams, P. E. V., Pagliani, L., Innes, G. M., Pennie, K., Harris, C. I. \& Garthwaite, P. (1987). British Journal of Nutrition 57, $417-428$. 